\title{
Assessment of combined glacier and tree-ring studies to constrain latitudinal climate forcing of Scandinavian glacier mass balances
}

\author{
Peter JANSSON, ${ }^{1}$ Hans W. LINDERHOLM ${ }^{2,3}$ \\ ${ }^{1}$ Department of Physical Geography and Quaternary Geology, Stockholm University, SE-106 91 Stockholm, Sweden \\ E-mail: peter.jansson@natgeo.su.se \\ ${ }^{2}$ Regional Climate Group, Earth Sciences Center, Göteborg University, SE-405 30 Göteborg, Sweden \\ ${ }^{3}$ Laboratory for Climate Studies, National Climate Centre, China Meteorological Administration, 46 Zhongguancun Nandajie, \\ Haidian District, Beijing 100081, China
}

\begin{abstract}
Assessing climate change and its effects on the cryosphere is important, and individual proxies are commonly used for such assessments. We have investigated the possibility of combining glacier mass balance and tree-ring data to better understand regional climate variability in Scandinavia. There are substantial differences between climate information in mass-balance and tree-ring data. Summer balance $\left(b_{\mathbf{S}}\right)$ is strongly related to summer temperature, while winter balance $\left(b_{\mathbf{W}}\right)$ is less readily interpreted in terms of a climate signal. Tree rings are good summer temperature proxies, but due to the complexity of tree growth factors (e.g. the effect of the previous winter's climate) tree-ring records do not exclusively represent summer temperatures. Combining $b_{\mathbf{S}}$ and tree-ring records will not likely yield additional summer climate information. The relationship of mass balance with the Arctic Oscillation is stronger than with the North Atlantic Oscillation, especially for northernmost Sweden, whereas no such correlations were found for tree-ring data. The agreement between $b_{\mathbf{N}}$ records from both maritime south-central Norway and continental northernmost Sweden and tree-ring data from Jämtland, in a maritime/continental climate transition zone, suggests possibilities to combine mass-balance and tree-ring data to provide information about climate over the entire year on interannual timescales.
\end{abstract}

\section{INTRODUCTION}

Climate-change effects on the cryosphere are of major importance to humanity (e.g. Bamber and Payne, 2004). Within the cryosphere, glaciers constitute an important water resource that is decreasing in volume on a worldwide scale in response to climate change (e.g. Hock and others, 2005). Analyses of a variety of climate proxy records can emphasize distinctions between natural long-term modes and anthropogenically induced climate variability. A large number of hemispheric and global climate reconstructions are available (e.g. Mann, 2002). However, these do not provide information about regional-scale variations, where regions with key climatic features may be masked in hemispheric or global reconstructions (Luterbacher and others, 2004). Consequently, studies of regional climate variability are important when climate impacts are evaluated (Shindell and others, 2003).

Climate variability in Scandinavia is likely to have been more complex than hemispheric or global mean climate changes indicate, with the role of atmospheric and ocean circulation changes, for example, playing a prominent role (personal communication from M.E. Mann, 2004). Thus, there is still much to be learned through continued detailed reconstructions of climate change in this particular region. Climate-related studies in Scandinavia have often been based on single-type climate proxy records. However, no single proxy is adequate for reconstructing past climate (Mann, 2002). Consequently, depending on the climate variable studied, climate proxies should be combined. Glacier mass balances and dendroclimatological data are two suitable proxies for studies of high-latitude climate variability; they may provide information on temperature, precipitation and the atmospheric circulation.
The role of atmospheric circulation in determining local to regional climate variability has been a focus of climate research in the past few decades. In the extratropical Northern Hemisphere, two major modes have been related to temperature and precipitation variations: the North Atlantic Oscillation (NAO) and the Arctic Oscillation $(\mathrm{AO})$. The NAO is usually defined by the difference in sea-level pressure between Iceland and the Azores, can be regarded as a measure of the strength of the westerly winds across the North Atlantic Ocean in the $40-60^{\circ} \mathrm{N}$ latitude belt (e.g. Greatbatch, 2000) and affects climate in the North Atlantic region (Hurrell, 1995; Osborn and others, 1999; Slonosky and Yiou, 2000). When the NAO is in a positive phase, the wintertime meridional pressure gradient over the North Atlantic is large, since the pressure gradients are strongest during the cool season (Hurrell and others, 2001), and this is associated with wetter and milder conditions than normal over Scandinavia (Hurrell, 1995). Thompson and Wallace (1998) introduced the term Arctic Oscillation, defined as a nearly axisymmetric spatial pattern of interannual variability of Northern Hemisphere winter sea-level pressure centered over the Arctic, which is more strongly coupled to Eurasian winter surface air temperatures than the NAO index. The $\mathrm{AO}$ is believed to be one of the leading modes of high-latitude variability (Fyfe and others, 1999) and may be a better indicator of the atmospheric mode of variability usually associated with the NAO (Greatbatch, 2000).

Year-to-year variations in glacier mass balance may be attributed to hemispheric-scale circulation. Walters and Meier (1989) showed how mass balances in Alaska, USA, and the Cascades of British Columbia, Canada/Washington State, USA, exhibit a seesaw pattern depending on the strength of the Aleutian low. When the low was strongly 


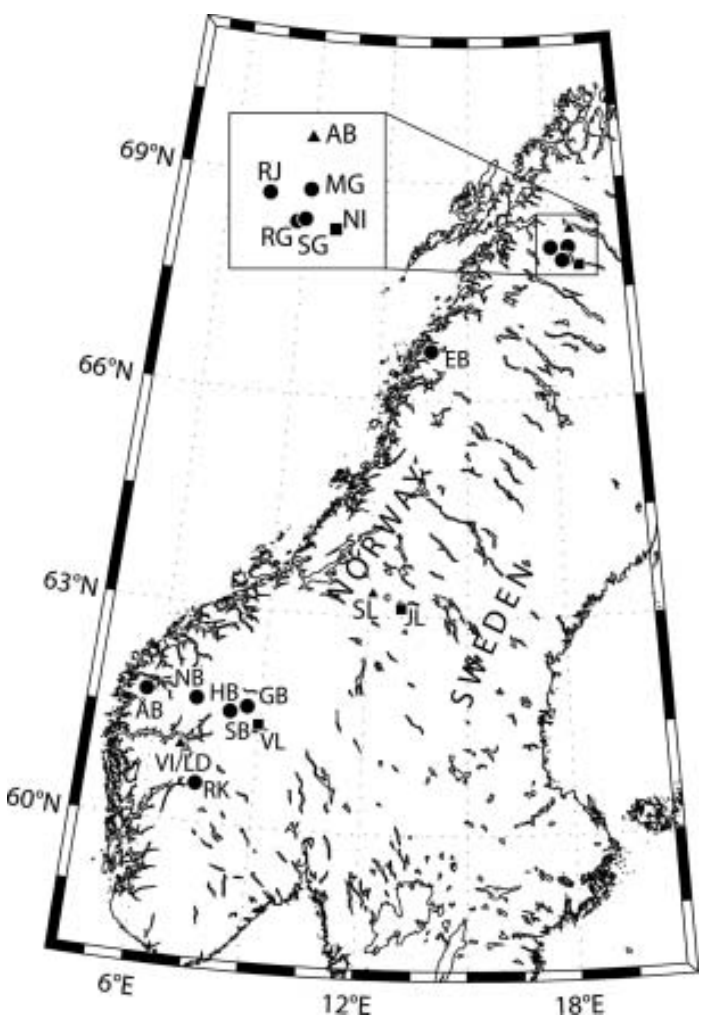

Fig. 1. Map of Scandinavia showing location of glaciers (filled circles), dendroclimatological chronologies (filled squares) and meteorological stations (filled triangles) used in this study. Abbreviations in the map: Northern Scandinavia: AB: Abisko (climate); EB: Engabreen; MG: Mårmaglaciären; NI: Nikkaluokta (chronology); RJ: Riukojietna; RG: Rabots glaciär; SG Storglaciären. Central Scandinavia: JL: Jämtland (chronology); SL: Storlien (climate). Southern Scandinavia: ÅB: Ålfotbreen; GB: Gråsubreen; HB: Hellstugubreen; VI: Vetti (precipitation); LD: Lærdal (temperature); NB: Nigardsbreen; RK: Rembesdalsskåka; SB: Storbreen; VL: Veolia (chronology).

developed, storms swung on a northerly path, yielding high winter balances in Alaska and leaving the southern areas starved of accumulation, and the opposite for a weakly developed low. Pohjola and Rogers (1997) studied similar relationships for the Scandinavian glaciers and found weak correlations between both the NAO and their own developed Norwegian Sea Index (NSI) and the mass balance of Storglaciären. Although the coupling is far from established, it is evident that larger-scale circulation affects regional signals in mass balance.

In the past, studies combining tree-ring and glacier fluctuation data have mainly focused on attempts to reconstruct climate fluctuations on decadal-to-century timescales (e.g. Matthews, 1977; Karlén, 1984; Luckman, 1993), or to infer past changes in glacier volume (Raper and others, 1996). However, both proxies have been analyzed for dependence on hemispheric circulation pattern, and relationships between different atmospheric circulation modes and mass-balance/tree-growth variability have been found (d'Arrigo and others, 1993, 2003; Pohjola and Rogers, 1997; McCabe and others, 2000; Nesje and others, 2000; Six and others, 2001; Cook and others, 2002).

In this paper, we explore the possibilities and benefits of combining annually resolved glacier mass-balance and treering data to further our understanding of how regional climate variability on intra-annual timescales in Scandinavia is connected to the atmospheric circulation.

\section{DATA}

\section{Mass-balance data}

Continuous records of annual glacier mass-balance records in Scandinavia now span > 50 years (e.g. Andreassen, 1999; Holmlund and Jansson, 1999; Holmlund and others, 2005, fig. 1) shows locations) and provide information on both summer and winter conditions. Winter balance is a more-orless complex function of precipitation and wind drifting (storminess) since snow precipitation is significantly redistributed in conjunction with or after reaching the ground. Summer balance is primarily a function of summer temperature, as is evident from reasonably good functional relationships between local ablation and elevation (e.g. Jansson, 1999) and between ablation and summer average temperature (e.g. Holmlund and others, 2005). However, secondary effects from radiation are also present (Hock, 1998). Hence, mass balance yields an integrated signal for both winter and summer seasons. It is important to recognize that the signal involves year-to-year differences in length of the seasons: a short, warm summer may yield the same result as a longer, cooler summer. Similarly, single intense precipitation events may produce significant portions of the winter budget. A single 6 day snowstorm in May 1986 yielded $10 \%$ of the winter balance for the 1984/85 mass-balance year $(H$. Grudd and P. Jansson, unpublished information).

Mass-balance data for all Scandinavian glaciers can be found in the World Glacier Monitoring Service Bulletins (e.g. Haeberli and others, 2003) as well as reports from the Norwegian Water Resources and Energy Directorate (NVE) (e.g. Kjøllmoen and others, 2003) and the Tarfala Research Station Annual Reports (e.g. Jansson, 2000). The Tarfala mass-balance program (Holmlund and Jansson, 1999) runs four long-term studies: Storglaciären (initiated in 1945), Rabots glaciär (1982), Mårmaglaciären (1987) and Riukojietna (1985). NVE (e.g. Kjøllmoen and others, 2003) monitors a large number of glaciers in Norway; we use the following: Storbreen (1949), Nigaardsbreen (1962), Ålfotbreen (1963), Engabreen (1970), Gråsubreen (1962), Rembesdalsskåka (1963) and Hellstugubreen (1962). The locations are shown in Figure 1.

\section{Dendroclimatological data}

Close to their limit of distribution in high altitudes or latitudes, the annual growth of trees will reflect local or regional summer temperatures (e.g. Fritts, 1976). Scots pine (Pinus sylvestris L.) tree-ring data are suitable for centuryto millennia-scale reconstructions/interpretations of highand low-frequency summer temperature variability along the Scandinavian Mountains (Briffa and others, 1992; Kalela-Brundin, 1999; Kirchhefer, 2001; Gunnarson and Linderholm, 2002). The Torneträsk chronology in northernmost Sweden reaches back to 5500 BP with annual resolution (Grudd and others, 2002), while the Jämtland chronology in the central Scandinavian Mountains presently spans $1600 \mathrm{BC}$ to AD 2000 (Linderholm and Gunnarson, 2005), with older trees dating back to $\sim 6600$ BP (Gunnarson and Linderholm, 2002). These two multi-millennial chronologies, although separated by $\sim 600 \mathrm{~km}$, correlate well, indicating a regional climate signal in tree-ring data along 
the Scandinavian Mountains. Although tree growth is primarily governed by air temperatures during the vegetation period, high precipitation (either as snow in the previous winter or as rain during summer) in the maritime central parts of Scandinavia may have negative effects on tree growth, especially during cold years. Consequently, the climate signal recorded in tree rings is not necessarily only a simple function of summer temperatures, but a combination of weather conditions prior to and during the actual vegetation period. In addition to temperature, tree-ring data from central Scandinavia have yielded information on humidity (Gunnarson, 2001) and winter precipitation variability (Linderholm and Gunnarson, 2005). Furthermore, changes in the atmospheric circulation are related to changes in pine growth rates and the growth/climate relationship in western Scandinavia, where negative growth trends in past decades are associated with the strong and positive phase of the NAO (Linderholm, 2002; Solberg and others, 2002; Linderholm and others, 2003).

To date, there are more than 60 tree-ring chronologies from Scandinavia, mainly located close to the tree limit along the Scandinavian Mountains. For this study, we selected Scots pine tree-ring width chronologies (TRW) from three sites: south-central Norway and northernmost Sweden, the areas where most glaciers are found, and central Scandinavia, an area almost devoid of glaciers (Fig. 1). At all sites, pines grow at the local tree limit, and annual radial growth is mainly limited by summer temperature. Nikkaluokta TRW (470 m a.s.l.) is close to the glaciers in the Kebnekaise massif in northern Sweden; Jämtland TRW (700 ma.s.I.) is situated in the central Scandinavian Mountains, near the Sweden-Norway border; and Veolia TRW (880 m a.s.I.; data obtained from the International Tree Ring Data Bank, http://www.ngdc.noaa.gov/-paleo/treering.html, collected and processed by F.H. Schweingruber) lies in the central highlands in south-central Norway, where numerous glaciers are found. Unfortunately, Veolia TRW ends in 1978 due to a lack of updating tree-ring data in southern Norway.

\section{ANALYSIS}

In this paper, we use published climate data on the AO (Thompson and Wallace, 1998) and NAO (Jones and others, 1997) to compare with mass-balance and dendroclimatological data.

\section{Mass-balance data}

To analyze the mass-balance records of Scandinavia, we performed simple correlation analyses of winter $\left(b_{\mathrm{W}}\right)$, summer, ( $b_{\mathrm{S}}$, a negative quantity), and net $\left(b_{\mathrm{N}}\right)$ balance as well as equilibrium-line altitudes (ELAs) of the glaciers with the longest mass-balance records.

The results for winter balance correlations (Fig. 2) indicate that the southern Norwegian glaciers all correlate well, with Gråsubreen as the only deviation. Within the northern region, glaciers also correlate relatively well. However, it is important to remember that the records for Mårmaglaciären, Riukojietna and Rabots glaciär in the north are relatively short. It is obvious that correlations between northern and southern glaciers are generally poorer than among glaciers in the northern and southern regions, respectively. Storglaciären seems to correlate better with glaciers in the south than other northern glaciers. This may be due to the shorter records for all other northern glaciers.
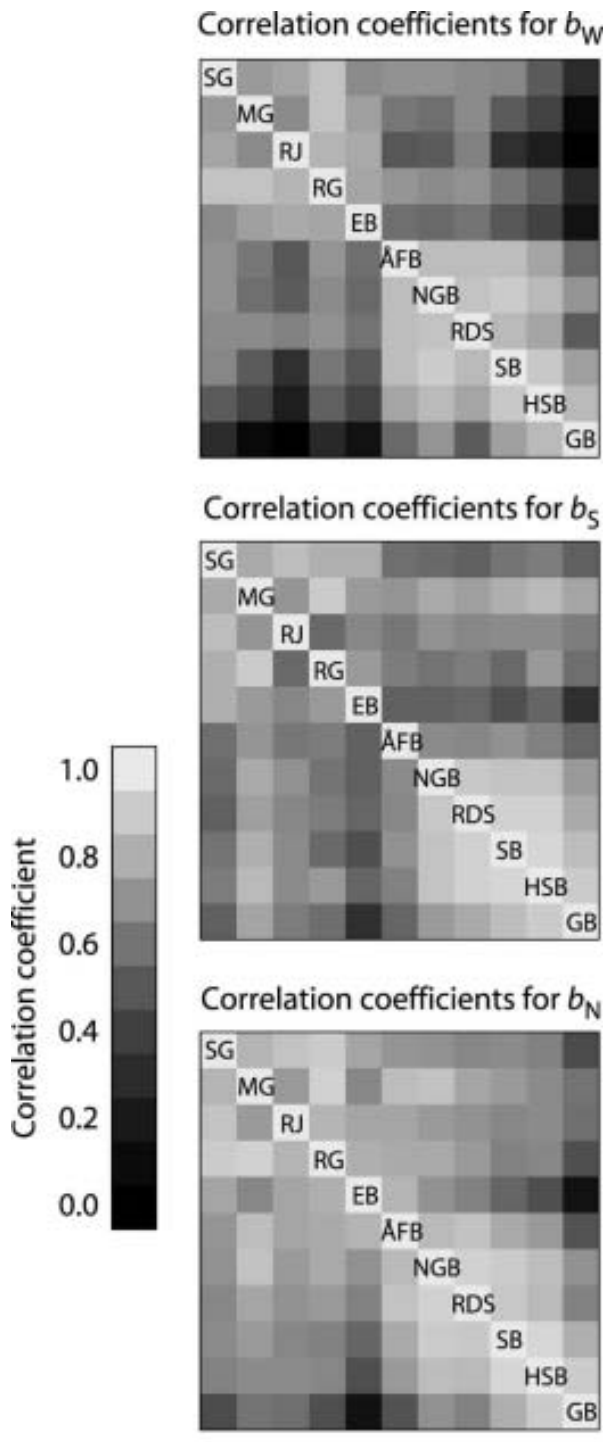

Correlation coefficients for ELA

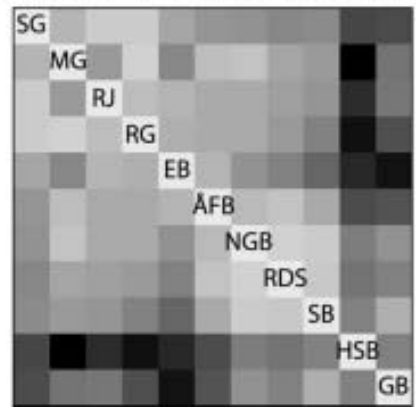

Fig. 2. Matrices of correlation coefficients for winter balance (a), summer balance (b), net balance (c) and ELA (d) for all glaciers shown in Figure 1. In general, correlation coefficients over 0.5 are significant at the 0.05 level.

Summer balances show a different pattern (Fig. 2). All glaciers in southern Norway, except the very maritime Alfotbreen, correlate well. The Ålfotbreen summer balance has been shown not to correlate with temperature but with wind and cloudiness (Østrem, 1973), implying that much melt occurs by heat released from condensation. G. Østrem (personal communication, 2004) also observed how runoff from the glacier was significantly decreased during an unusual 2 week fair-weather period, which also corroborates 
Table 1. Description of chronologies and meteorological stations

\begin{tabular}{|c|c|c|c|}
\hline Tree-ring chronology & $\begin{array}{l}\text { Elevation } \\
\text { ma.s.I. }\end{array}$ & \multicolumn{2}{|c|}{ Chronology span } \\
\hline $\begin{array}{l}\text { Nikkaluokta } \\
\text { Jämtland } \\
\text { Veolia }\end{array}$ & $\begin{array}{l}470 \\
700 \\
880\end{array}$ & $\begin{array}{l}163 \\
147 \\
175\end{array}$ & $\begin{array}{l}-2000 \\
-2002 \\
-1978\end{array}$ \\
\hline Meteorological station & $\begin{array}{l}\text { Elevation } \\
\text { ma.s.l. }\end{array}$ & $\begin{array}{l}\text { Temperature } \\
\text { Dec./Jul. } \\
{ }^{\circ} \mathrm{C}\end{array}$ & $\begin{array}{l}\text { Precipitation* } \\
\text { Dec./Jul. } \\
\text { mm }\end{array}$ \\
\hline $\begin{array}{l}\text { Abisko }{ }^{\dagger} \\
\text { Storlien } \\
\text { Lærdal } \\
\text { Vetti }\end{array}$ & $\begin{array}{l}288 \\
642 \\
36 \\
329\end{array}$ & $\begin{array}{l}-9.1 / 11.0 \\
6.9 / 11.1 \\
1.2 / 14.7 \\
-\end{array}$ & $\begin{array}{l}26 / 54 \\
82 / 106 \\
- \\
96 / 74\end{array}$ \\
\hline
\end{tabular}

the dependence of melting on condensation in the area. The glacier thus experiences much less interannual variability than the more continental glaciers further inland. In the north, Storglaciären and Engabreen correlate well because the distance between the glaciers does not permit larger differences in synoptic conditions during summer. Correlations among the other glaciers are relatively high, but weaker than the Storglaciären-Engabreen correlation, probably due to the lower number of data points in the analysis. A north-south difference in summer balance is not as obvious as for the winter balance, but it is present.

The net balance correlations are generally better than those for winter and summer balances (Fig. 2). This is surprising since the winter balance correlations are regionally good but show interregional differences, and summer balance correlations have a similar pattern but with relatively higher correlation coefficients. Since net balance is the sum of winter and summer balances, $b_{\mathrm{N}}=b_{\mathrm{W}}+b_{\mathrm{S}}$, our result indicates that summer and winter balances must be offsetting, producing a less marked north-south difference and generally higher correlations between glacier balances.

ELAs are a function of the net balances on the glaciers. Correlation coefficients (Fig. 2) are generally lower than for the net balances.

\section{Dendroclimatological data}

For the pine-growth/climate analyses, tree-ring series were standardized by the removal of age-associated trends to maximize high-frequency variations (Fritts, 1976), and since we wanted to maximize high-frequency variability in the datasets, we used the residual chronologies, computed by removing autocorrelation from the individual series. The relationship between pine growth and climate was established by correlation analysis, using annual tree-ring residuals, mean monthly temperature and total monthly precipitation (Table 1). To incorporate the effect on tree growth of previous fall and winter climate, as well as conditions during the growth season, the period of analysis covered September of the preceding year to August of the growth year. Temperature and precipitation data were obtained from the closest meteorological stations with long
Temperature
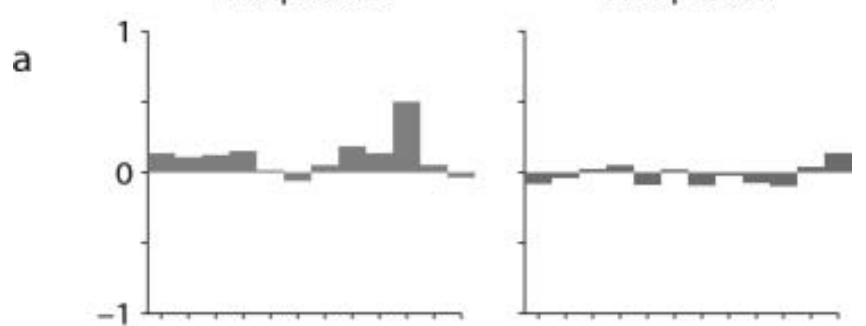

b
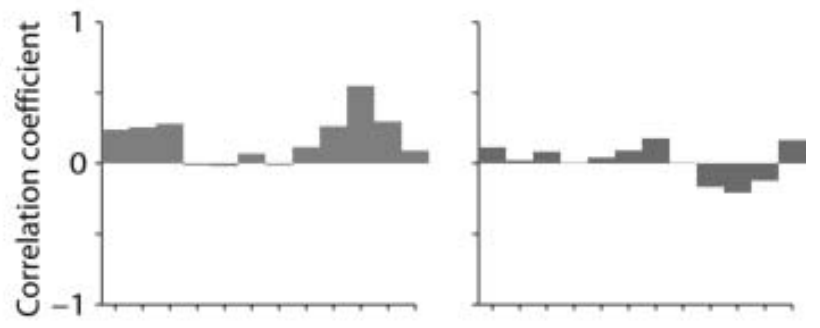

C

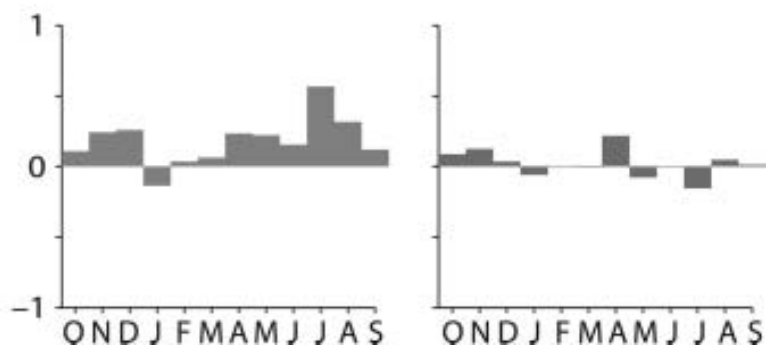

Fig. 3. Coefficients for correlation between monthly climate and Scots pine tree-ring residuals. Each bar represents the correlation coefficient between tree growth and mean temperature (black bars) and total precipitation (white bars) for a given month from previous October to current September. (a) Nikkaluokta; (b) Jämtland; and (c) Veolia.

coverage. Strong correlation between pine growth and July temperatures is found at all sites (Fig. 3), but in Jämtland tree growth seems to be more influenced by temperatures throughout summer than at the other sites. Furthermore, it is clear that precipitation has a limited effect on pine growth at the studied sites, although summer precipitation tends to have a negative effect on pine growth in Jämtland.

\section{DISCUSSION}

\section{Mass balance}

In general, summer balances correlate better over Scandinavia than winter balances, which have a pronounced north-south difference. This indicates that summer conditions, primarily average summer temperature, affect most Scandinavian glaciers in a similar way. This is most likely due to the regional homogeneity of summer temperatures in Scandinavia, whereas the winter conditions differ between the northern and southern regions. The explanation for this may be the position of the Arctic Front (AF) during winter. It is more likely that the AF passes the northern than the southern region. This means that storm tracks may be diverted in an apparent seesaw pattern relative to the two regions, depending on whether the $\mathrm{AF}$ is in a northerly or southerly position. It is important to realize that the seesaw may be a consequence of the separation distance between the two glacierized areas of northern and southern Scandinavia. 


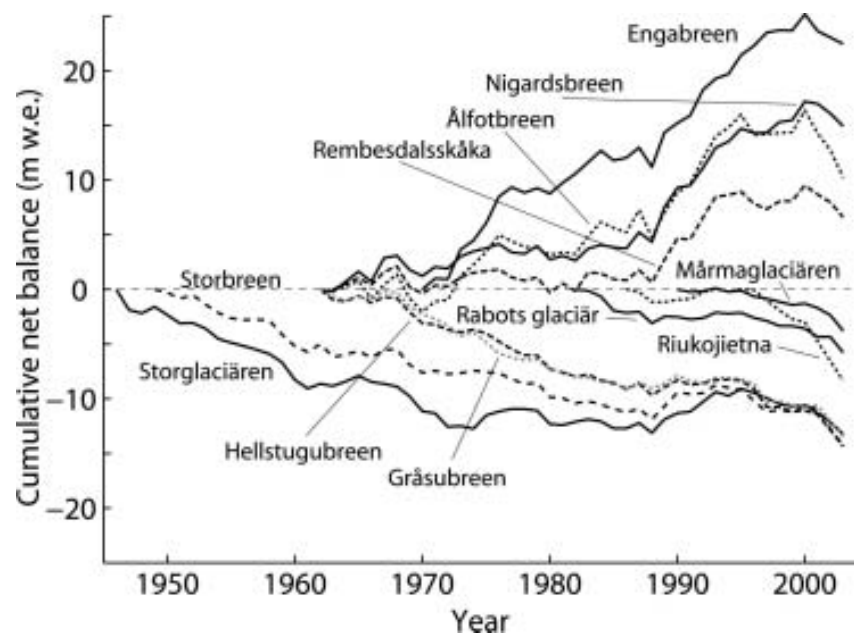

Fig. 4. Cumulative net balances for all glaciers in the study. All balances start at an arbitrary zero balance.

ELAs are a function of the net balances on the glaciers. Correlation coefficients (Fig. 2) are generally lower than for the net balances. This indicates that ELA may not be such a good approximation for net balance as has been suggested by Dyurgerov (1996). This may be due to the presence of very thick snowpatches around the glacier edges and in front of glacier termini on some continental glaciers, which distorts the net balance gradient.

Strong correlations between net balances indicate that the year-to-year variability in net balance is similar between glaciers. This does not provide indications for the state of glacier volume change. The cumulative net balance curves for all glaciers in this study are shown in Figure 4. The curves indicate that the cumulative net balance, equivalent to a volume change of the glacier, varies between glaciers and may also have different signs indicating that glaciers may be both increasing and decreasing despite being correlated in terms of year-to-year variability. It is important to remember that what is actually measured in mass-balance measurements is the change in mass per year, or rate of mass change. The cumulative curve is thus the integration of the annual rates. High correlation coefficients between mass-balance records imply that rate changes are correlated but say nothing about the magnitude. Similar rate changes may thus result in either positive or negative volume change.

\section{Dendroclimatological data}

Despite good agreement among the tree-ring data, due to the common growth responses to summer temperatures, there are clear distinctions between Nikkaluokta/Veolia and Jämtland. Pine growth at Nikkaluokta/Veolia is first and foremost determined by July temperatures, as expected close to the latitudinal (Nikkaluokta) or altitudinal (Veolia) tree line. Furthermore, both chronologies come from sites located at some distance from the Norwegian Sea, compared to Jämtland. In Jämtland, pines grow on the border between continental climate (east of the Scandinavian Mountains) and maritime climate (west of the mountains), and in this semi-maritime climate there is an additional effect of precipitation to that of temperature. The influence of winter precipitation on pine growth in Jämtland and its linkage to large-scale atmospheric variability has been described previously (Linderholm, 2002; Linderholm and Gunnarson, 2005). In short, high amounts of winter

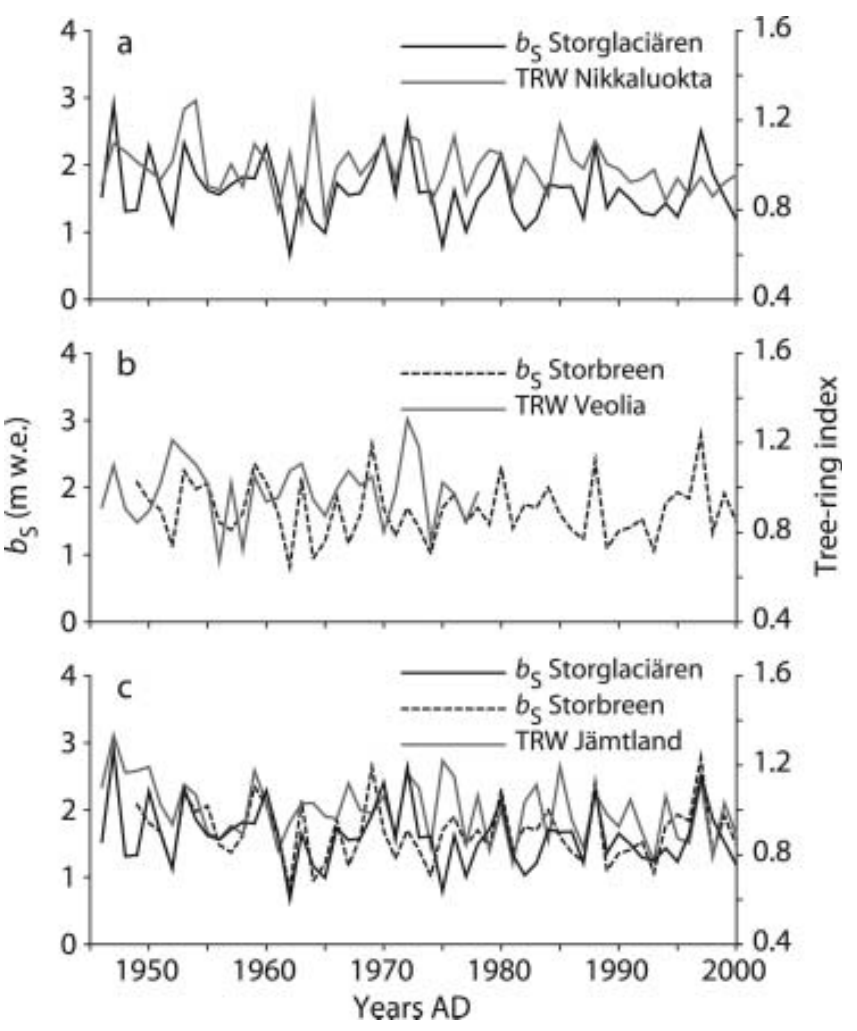

Fig. 5. Residual tree-ring width chronologies (TRW) plotted against glacier summer balance records $\left(b_{\mathrm{s}}\right)$. (a) Nikkaluokta vs Storglaciären; (b) Veolia vs Storbreen; and (c) Jämtland vs Storglaciären and Storbreen.

precipitation, yielding a sustained snow cover that could last into late spring, may cause later initiation of cambial activity and contribute to over-saturation of soils well into summer, especially on mountain slopes that are less exposed to the sun, which in a maritime climate could result in periodically anoxic conditions and consequently poorer growth conditions. It should be noted that this effect is not necessarily instantaneous: the effect of high winter precipitation may not show up in the subsequent summer's pine growth, but in one or more years after (Linderholm and Gunnarson, 2005).

\section{Synthesis}

To decide to what extent the two studied climate proxy records were related and, hence, can be combined to yield further climate information, the mass-balance records with the longest measurement series were compared to the treering data from the two main regions. Consequently, the maritime climate regime of south-central Norway was represented by mass-balance data from Storbreen and treering data from Veolia, while the more continental climate of northernmost Sweden was represented by mass-balance data from Storglaciären and tree-ring data from Nikkaluokta. Tree-ring data alone from Jämtland (due to lack of massbalance data from the region) represented a transition zone between the two climate regimes. From Figure 5 and Table 2 it is clear that the correspondence between $b_{\mathrm{S}}$ and tree growth is low in both regions; in fact, tree growth in Jämtland was better correlated to the $b_{\mathrm{S}}$ records than local tree growth. This lack of correspondence between glacier $b_{\mathrm{S}}$ and tree growth is a consequence of the complexity of tree growth responses to climate, where trees will react not only to one parameter but to a combination of parameters (Fritts, 
Table 2. Correlation matrix of mass balance, tree-ring residuals and atmospheric circulation indices, 1946-2000. Bold numbers denote significance at the 0.05 level

\begin{tabular}{|c|c|c|c|c|c|c|c|c|c|}
\hline & $\mathrm{NL} \operatorname{trR}$ & $J \mathrm{~L} \operatorname{trR}$ & $V L \operatorname{tr} R$ & $\mathrm{AO} A$ & NAO A & $\mathrm{AO} W$ & NAO W & $\mathrm{AOS}$ & NAO S \\
\hline SG $b_{\mathrm{N}}$ & -0.20 & -0.29 & -0.13 & 0.57 & 0.32 & & & & \\
\hline $\mathrm{SB} b_{\mathrm{N}}{ }^{*}$ & -0.08 & -0.27 & -0.10 & 0.62 & 0.54 & & & & \\
\hline SG $b_{\mathrm{W}}$ & 0.00 & -0.08 & 0.01 & & & 0.69 & 0.37 & & \\
\hline SB $b_{\mathrm{w}}{ }^{*}$ & -0.02 & 0.03 & 0.02 & & & 0.72 & 0.59 & & \\
\hline SG $b_{\mathrm{S}}$ & 0.30 & 0.35 & 0.18 & & & & & 0.03 & 0.03 \\
\hline $\mathrm{SB} b_{\mathrm{S}}{ }^{*}$ & 0.10 & 0.41 & 0.14 & & & & & 0.08 & -0.16 \\
\hline$N L \operatorname{trR}^{* *}$ & - & 0.49 & 0.44 & 0.10 & 0.10 & 0.11 & 0.13 & 0.02 & -0.04 \\
\hline $\mathrm{JL} \operatorname{trR}$ & 0.49 & - & 0.36 & 0.09 & 0.10 & 0.06 & 0.09 & 0.14 & 0.05 \\
\hline $\mathrm{VL} \operatorname{trR}$ & 0.44 & 0.36 & - & 0.21 & 0.00 & 0.17 & -0.02 & 0.31 & 0.04 \\
\hline $\mathrm{AO} \mathrm{A**}$ & & & & - & 0.70 & & & & \\
\hline $\mathrm{AO} \mathrm{W}^{* * *}$ & & & & & & - & 0.67 & & \\
\hline $\mathrm{AO} \mathrm{S}^{* * *}$ & & & & & & & & - & 0.35 \\
\hline
\end{tabular}

SG: Storglaciären; SB: Storbreen; NL: Nikkaluokta; JL: Jämtland; VL: Veolia. AO: Arctic Oscillation (Thompson and Wallace, 1998); NAO: North Atlantic Oscillation (from Jones and others, 1997). $b_{\mathrm{N}}$ : net balance; $b_{\mathrm{W}}$ : winter balance; $b_{\mathrm{S}}$ : summer balance; trR: tree-ring residuals. A: annual (here SeptemberAugust); W: winter (here September-May); S: summer (here June-August).

*Record begins 1949. ${ }^{* *}$ Record ends $1978 .{ }^{* * *}$ Record ends 1996.

1976; see above). The only exception was found in Jämtland, where there was a correlation of almost 0.3 between Scots pine growth residuals and $b_{\mathrm{N}}$ of both Storbreen and Storglaciären (Fig. 6). Thus, tree-ring data in Jämtland seem to have the quality of being comparable to annual glacier mass-balance data, since they contain information about winter as well as summer climate.

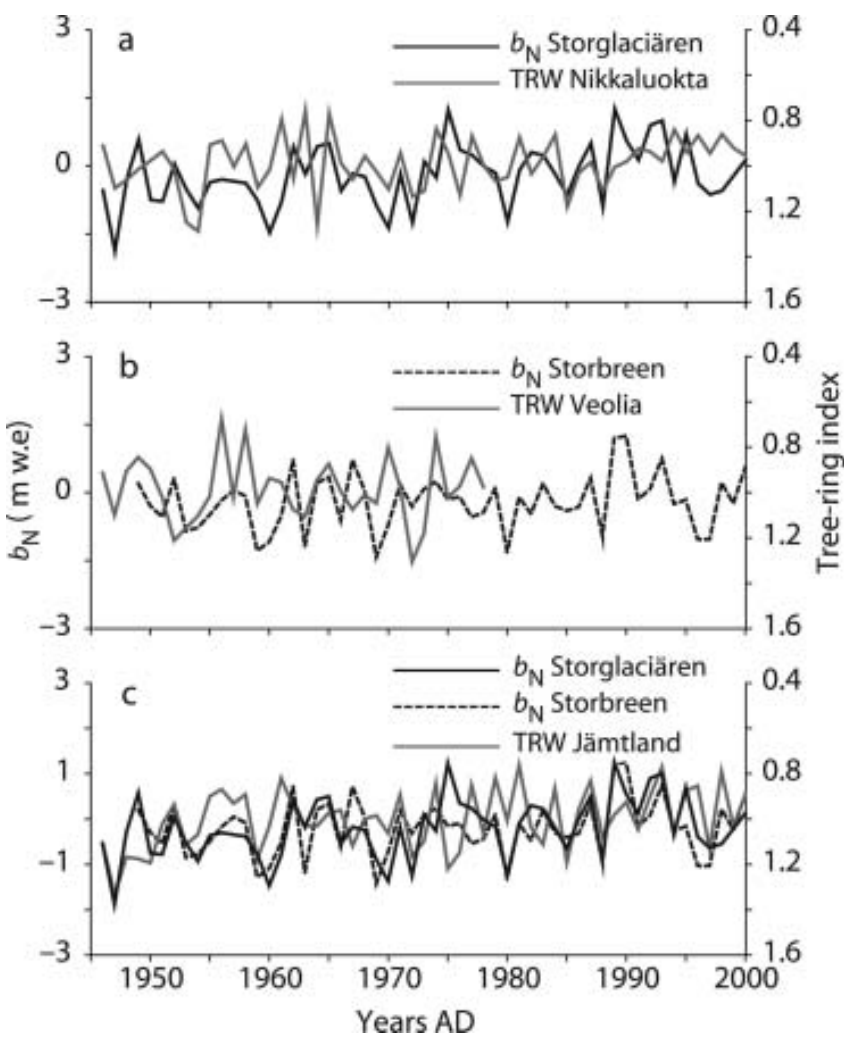

Fig. 6. Residual tree-ring chronologies plotted against glacier net balance records $\left(b_{N}\right)$. (a) Nikkaluokta vs Storglaciären; (b) Veolia vs Storbreen; and (c) Jämtland vs Storglaciären and Storbreen. Note the inverted scale on the righthand axes.
Similar to previous studies (Nesje and others, 2000; Nesje and Dahl, 2003), we found that $b_{\mathrm{N}}$ and $b_{\mathrm{W}}$ in south-central Norway are better correlated to the NAO than in northernmost Sweden. This is due to the progressively decreasing influence on climate of the NAO over $60^{\circ} \mathrm{N}$ (e.g. Greatbatch, 2000). It is possible that the differences in the massbalance records of the two regions can be explained by regional differences in the atmospheric circulation.

In addition, we found an even stronger correspondence between $b_{\mathrm{N}}$ and $b_{\mathrm{W}}$ with the $\mathrm{AO}$, especially at Storglaciären. Therefore, the AO may be a better index to use when investigating the link between glacier mass balance and the atmospheric circulation in high northern latitudes. Scots pine growth in the Scandinavian Mountains does not seem to respond to atmospheric circulation variability on intraannual timescales, most likely due to the slight influence on vegetation period temperatures from the AO/NAO.

\section{CONCLUSIONS}

There are substantial differences between the climate information in glacier mass-balance data and that in treering data. While there is a strong relationship between summer temperatures and glacier $b_{\mathrm{S}}$, the climate signal in $b_{\mathrm{w}}$ is less readily interpreted. Similarly, tree rings are also good proxies for summer temperatures, but due to the complexity of tree growth factors other than climate, climate outside the vegetation period may also affect growth. Thus, combining glacier $b_{\mathrm{S}}$ and tree-ring records will likely not yield additional information about summer temperatures. Furthermore, there are strong relationships between the atmospheric circulation, $b_{\mathrm{w}}$ and $b_{\mathrm{S}}$ in Scandinavia, correlations being highest during the winter season. The mass-balance/ atmospheric circulation relationship is stronger using the $\mathrm{AO}$ than the NAO, especially in northernmost Sweden. Periods of diverging mass-balance records from the two areas are possibly due to regional differences in the atmospheric circulation. There was no correspondence between tree growth and AO/NAO. The agreement between $b_{\mathrm{N}}$ records from both maritime south-central Norway and continental 
northernmost Sweden and tree-ring data from Jämtland, in a transition zone between maritime and continental, suggests that mass-balance and tree-ring records from these areas may be combined to give information about climate, as a function of temperature and atmospheric circulation, over the entire year on intra-annual timescales.

\section{ACKNOWLEDGEMENTS}

Sincere thanks to everyone involved in collecting massbalance and dendroclimatological data over the years. Critical comments from A. Nesje and $\varnothing$. Lie helped to improve the paper. N. Haakensen of the NVE provided an in-depth explanation of local Norwegian naming conventions. G. Østrem provided useful information on melt conditions at Norwegian glaciers.

\section{REFERENCES}

Andreassen, L.M. 1999. Comparing traditional mass balance measurements with long-term volume change extracted from topographical maps: a case study of Storbreen glacier in Jotunheimen, Norway, for the period 1940-1997. Geogr. Ann., 81A(4), 467-476.

Bamber, J.L. and A.J. Payne. 2004. Mass balance of the cryosphere: observations and modelling of contemporary and future changes. Cambridge, Cambridge University Press.

Briffa, K.R. and 7 others. 1992. Fennoscandian summers from A.D. 500: temperature changes on short and long timescales. Climate Dyn., 7, 111-119.

Cook, E.R., R.D. d'Arrigo and M.E. Mann. 2002. A well-verified, multiproxy reconstruction of the winter North Atlantic Oscillation index since AD 1400. J. Climate, 15, 1754-1764.

d'Arrigo, R.D., E.R. Cook, G.C. Jacoby and K.R. Briffa. 1993. NAO and sea surface temperature signatures in tree-ring records from the North Atlantic sector. Quat. Sci. Rev., 12, 431-440.

d'Arrigo, R.D., E.R. Cook, M.E. Mann and G.C. Jacoby. 2003. Treering reconstructions of temperature and sea-level pressure variability associated with the warm-season Arctic Oscillation since AD 1650. Geophys. Res. Lett., 30(11), 1549. (10.1029/ 2003GL017250.)

Dyurgerov, M. 1996. Substitution of long-term mass balance data by measurements of one summer. Z. Gletscherkd. Glazialgeol., 32, 177-184.

Fritts, H.C. 1976. Tree rings and climate, London, Academic Press.

Fyfe, J.C., G.J. Boer and G.M. Flato. 1999. The Arctic and Antarctic oscillations and their projected changes under global warming. Geophys. Res. Lett., 26(11), 1601-1604.

Greatbatch, R.J. 2000. The North Atlantic Oscillation. Stochastic Environ. Res. Risk Assess., 14(4-5), 213-242.

Grudd, H., K.R. Briffa, W. Karlén, T.S. Bartholin, P.D. Jones and B. Kromer. 2002. A 7400-year tree-ring chronology in northern Swedish Lapland: natural climate variability expressed on annual to millennial timescales. The Holocene, 12(6), 657-665.

Gunnarson, B.E. 2001. Lake level changes indicated by dendrochronology on subfossil pine, Jämtland, central Scandinavian Mountains, Sweden. Arct. Antarct. Alp. Res., 33(3), 274-281.

Gunnarson, B.E. and H.W. Linderholm. 2002. Low frequency climate variation in Scandinavia since the 10th century inferred from tree rings. The Holocene, 12, 667-671.

Haeberli, W., R. Frauenfelder, M. Hoelzle and M. Zemp, eds. 2003. Glacier Mass Balance Bulletin No. 7 (2000-2001). Zürich, IAHS(ICSI)-UNEP-UNESCO-WMO.

Hock, R. 1998. Modelling of glacier melt and discharge. Zürcher Geogr. Schr. 70.

Hock, R., P. Jansson and L. Braun. 2005. Modelling the response of mountain glacier discharge to climate warming. In Huber, U.M., H.K.M. Bugmann and M.A. Reasoner, eds. Global change and mountain regions: a state of knowledge overview. Dordrecht, Springer, 243-252. (Advances in Global Change Research 23.)

Holmlund, P. and P. Jansson. 1999. The Tarfala mass balance programme. Geogr. Ann., 81A(4), 621-631.

Holmlund, P., P. Jansson and R. Pettersson. 2005. A re-analysis of the 58 year mass-balance record of Storglaciären. Ann. Glaciol., 42 (see paper in this volume).

Hurrell, J.W. 1995. Decadal trends in the North Atlantic Oscillation: regional temperature and precipitation. Science, 269(5224), 676-679.

Hurrell, J.W., Y. Kushnir and M. Visbeck. 2001. The North Atlantic Oscillation. Science, 291(5504), 603-605.

Jansson, P. 1999. Effect of uncertainties in measured variables on the calculated mass balance of Storglaciären. Geogr. Ann., 81A(4), 633-642.

Jansson, P. 2000. Mass balance of Storglaciären 1998/1999. In Klingbjer, P., ed. Tarfala Research Station Annual Report 199899. Forskningsrapport 11, 7-10.

Jones, P.D., T. Jónsson and D. Wheeler. 1997. Extension to the North Atlantic Oscillation using early instrumental pressure observations from Gibraltar and South-West Iceland. Int. J. Climatol., 17, 1433-1450.

Kalela-Brundin, M. 1999. Climatic information from tree-rings of Pinus sylvestris $L$. and a reconstruction of summer temperatures back to AD 1500 in Femundsmarka, eastern Norway, using partial least squares regression (PLS) analysis. The Holocene, 9(1), 59-77

Karlén, W. 1984. Dendrochronology, mass balance and glacier front fluctuations in northern Sweden. In Mörner, N.-A. and W. Karlén, eds. Climatic changes on a yearly to millennial basis. D. Reidel Publishing Company, 263-271.

Kirchhefer, A.J. 2001. Reconstruction of summer temperatures from tree-rings of Scots pine (Pinus sylvestris L.) in coastal northern Norway. The Holocene, 11(1), 41-52.

Kjøllmoen, B., L.M. Andreassen, R.V. Engeset, H. Elvehøy and M. Jackson. 2003. Glaciological investigations in Norway in 2002. NVE Rep. 3.

Linderholm, H.W. 2002. Twentieth-century Scots pine growth variations in the central Scandinavian Mountains related to climate change. Arct. Antarct. Alp. Res., 34(4), 440-449.

Linderholm, H.W. and B.E. Gunnarson. 2005. Summer climate variability in west-central Fennoscandia during the last 3600 years. Geogr. Ann., 87A(1), 231-241.

Linderholm, H.W., B.Ø. Solberg and M. Lindholm. 2003. Tree-ring records from central Fennoscandia: the relationship between tree growth and climate along an east west transect. The Holocene, 13(6), 887-895.

Luckman, B.H. 1993. Glacier fluctuation and tree-ring records for the last millennium in the Canadian Rockies. Quat. Sci. Rev., 12(6), 441-450.

Luterbacher, J., D. Dietrich, E. Xoplaki, M. Grosjean and H. Wanner. 2004. European seasonal and annual temperature variability, trends, and extremes since 1500. Science, 303(5663), 1499-1503.

Mann, M.E. 2002. The value of multiple proxies. Science, 297(5586), 1481-1482.

Matthews, J.A. 1977. Glacier and climatic fluctuations inferred from tree-growth variations over the last 250 years, central southern Norway. Boreas, 6(1), 1-24.

McCabe, G.J., A.G. Fountain and M. Dyurgerov. 2000. Variability in winter mass balance of northern hemisphere glaciers and relations with atmospheric circulation. Arct. Antarct. Alp. Res., 32(1), 64-72.

Nesje, A. and S.O. Dahl. 2003. The 'Little Ice Age' - only temperature? Holocene, 13(1), 139-145.

Nesje, A., Ø. Lie and S.O. Dahl. 2000. Is the North Atlantic Oscillation reflected in Scandinavian glacier mass balance records? J. Quat. Sci., 15(6), 587-601. 
Osborn, T.J., K.R. Briffa, S.F.B. Tett, P.D. Jones and R.M. Trigo. 1999. Evaluation of the North Atlantic Oscillation as simulated by a coupled climate model. Climate Dyn., 15(9), 685-702.

Østrem, G. 1973. Runoff forecasts for highly glacierized basins. International Association of Hydrological Sciences Publication 107 (Proceedings of the Banff symposium, September 1972 The Role of Snow and Ice in Hydrology), 1111-1132.

Pohjola, V.A. and J.C. Rogers. 1997. Atmospheric circulation and variations in Scandinavian glacier mass balance. Quat. Res., 47(1), 29-36.

Raper, S.C.B., K.R. Briffa and T.M.L. Wigley. 1996. Glacier change in northern Sweden from AD 500: a simple geometric model of Storglaciären. J. Glaciol., 42(141), 341-351.

Shindell, D.T., G.A. Schmidt, R.L. Miller and M.E. Mann. 2003. Volcanic and solar forcing of climate change during the preindustrial era. J. Climate, 16(24), 4094-4107.

Six, D., L. Reynaud and A. Letréguilly. 2001. Bilans de masse des glaciers alpins et scandinaves, leurs relations avec l'oscillation du climat de l'Atlantique nord. Comptes Rendus de l'Académie des Science-Series IIA - Earth and Planetary Science, 333, 693-698.

Slonosky, V. and P. Yiou. 2000. Does the NAO index represent zonal flow? The influence of the NAO on North Atlantic surface temperature. Climate Dyn., 19(1), 17-30.

Solberg, B.Ø., A. Hofgaard and H. Hytteborn. 2002. Shifts in radial growth responses of coastal Picea abies induced by climatic change during the 20th century, central Norway. Ecoscience, 9, 79-88.

Thompson, D.W.J. and J.W. Wallace. 1998. The Arctic Oscillation signature in the wintertime geopotential height and temperature fields. Geophys. Res. Lett., 25(9), 1297-1300.

Walters, R.A. and M.F. Meier. 1989. Variability of glacier mass balances in western North America. In Paterson, D.H., ed. Aspects of climate variability in the Pacific and western Americas. Washington, DC, American Geophysical Union, 365-374. (Geophysical Monograph 55.) 